\title{
The Strengthening of Conservation Value in Listening Learning
}

\author{
Deby Luriawati Naryatmojo \\ \{debyluriawati@mail.unnes.ac.id\} \\ Universitas Negeri Semarang
}

\begin{abstract}
The research aims to know the result of strengthening of conservation value in listening learning of the students of Indonesian Language and Literature Department of Semarang State University. The method of the research is classroom action research. The data collection technique is done by test and non test techniques. The data analysis uses qualitative including description, interpretation, and reflection to the things happened in teaching learning process. The result of the research shows the increase that is $22,5 \%$ of 65 in cycle I becomes 87 in cycle II. There is the students' behavior change to be positive in cycle II, the students look more enthusiastic and excited during the listening learning.
\end{abstract}

Keywords : learning, conservation value, listening comprehension skill

\section{Introduction}

The policy of Semarang State University (UNNES) as the conservation insightful university brings the logical consequence to color the university members' life and cover all Tridharma activity programs also academic culture. Besides that, UNNES upholds well the principles of protection, preservation, and wise use of natural resources and respect for cultural heritage and the noble civilization of the nation. Through this conservation, humanistic values can be implemented in subject learning as cultural conservation programs.

One of the courses taught by the Indonesian Language and Literature Education (BSI) of UNNES program is Listening Skill. Listening skill learns about science in which is effective listening theory, comprehensive listening, and creative listening. In the 2006 curriculum structure, listening skill subject ( 2 semester credits) awarded in semester 1.

Listening skill course becomes basic course in Indonesian language and literature program (BSI) so that students' understanding of each sub-competency of listening skills is expected to be absorbed by students to achieve maximum learning outcomes. However, based on 2014/2015 academic year data, it showed that the students who got an A grade of 5\%, had an $\mathrm{AB}$ grade to $\mathrm{B}$ as much as $19 \%, \mathrm{BC}$ to $\mathrm{C}$ as much as $76 \%$. The course score profile showed that only about a quarter of students who took the course could achieve good competency Naryatmojo [1] From the results of the survey in the field, students assume that listening skill is less desirable because they are learning subject that learns about understanding of information. The low scores of students are also influenced by a lack of interest in learning because some students still consider the subject of listening skill to be unpleasant and can be done on their own[2]. 
Referring to the results of the examination, the low interest in student learning, the number of subject matter that is theoretical, then it is needed to increase the interest and motivation of students in learning listening skill. Some researches that took the listening skill had the result that there must be model, strategy, media, evaluation tools, and even the value of conservation content that can be implemented in order to improve students' achievement in listening learning.

"Toward a New Methodology for Learning “ in ELT Journal reveals the use of sub skill in listening exercise can improve listening skill. The advantage of using sub skill is that it can detect student weaknesses in each learning being taught, so that the teacher is easy to determine the failure of learning and improve it immediately to obtain good skills.

In line with Fielad [3] also explained the listening skill strategy. In his article entitled "Uncovering Listening Strategies: Protocol Analysis as a Means to Investigate Student Listening in The Basic Communication Course" explained that in order to learn cognitive listening strategies, students must use a protocol analysis, (that is technique based on verbal reports / delivered verbally by expressing their thoughts after they have listened) in University. The findings in this study were to find out the improvement in the process of listening to students on campus in a basic speech communication program.

Research on listening learning revealed The ability to take what those ears hear, properly discern the sound, and then act accordingly to fix any subtle recorded audio problems, makes all the difference in the quality of the final tracks and master[4], Pamela Leintz, Nevers Barbara, Susan Thomson [5] in the International Journal of Intercultural Relations " Learning through listening: Applying an action learning model to a cross-cultural field study experience in Native America". This approach took students out of the traditional post-secondary classroom setting for 1 week and emphasized learning through active listening and the creation of partnerships between students, the teaching team, and community stakeholders. Our hybridized teaching model is based on Freire's (Pedagogy of the oppressed, Contimurm, New York, 1970) problem-posing approach and combines a number of pedagogical techniques including experiential learning, collaborative models of group learning, the use of field experience and the use of the Internet

In learning listening skill, Luchini [6] revealed various problems that could be used as a basis for learning. In the Journal of Language Studies entitled "Listening Skill Teaching: Some Pedagogical Considerations" explained that the factors underlying listening skill were motivation, self-confidence, and anxiety related to language acquisition. The results of this study stated that pronunciation related to the speaker's accent, segmental characteristic, speech level, affective factor, environmental factor, listening material, and skill were fundamental in listening activity. There has been a constant move from a purely linguistic listening perception towards one which includes many aspects and facets in relation to the cultural constructs, topic familiarity, discourse clues and pragmatic conventions[7]

Research on listening skill and the application of learning strategies had also been done by [8]. Research published in Journal System 36, with the title "Listening Comprehension and Strategy Use: a Longitudinal Exploration" produced findings (1) the use of strategies developed over time in students who had different scores in the listening test, (2) the verbalization actions interfered with the process of listening, (3) the subjects could remember correctly the strategies used for high school students.

Research describe research findings showing that young L1 listeners adopt various different strategies in differently structured situations. In particular, I show that nouns, particularly argument nouns, appear to be preferentially selected for attention when subjects are asked to listen under stressful conditions[9] 
In line with Graham et al, Frunza [10] also conducted a research on listening activity strategies . In a study entitled "The Effects of Visual Strategies on Textual Structures in Listening Processes to Comprehension Levels of the Listeners" and published in the journal Procedia Social and Behavioral Sciences. This study found the influence of the schematic structure of story text as a visual strategy on comprehension. The effect of this schematic structure could increase students' understanding. The increase could be seen in listening activity that used the schematic structure of story as visual strategy in the classroom environment.

Based on observations at several universities in Central Java, including the University of Panca Sakti Tegal, Pekalongan University, IKIP PGRI Semarang, Sebelas Maret University, and Jendral Soedirman University showed that in listening skill learning, student learning activities only touched on the cognitive domain, that are aspects of memory and understanding, while the affective and psychomotor domains are ignored. In fact, in listening learning the three domains must be implemented in so that learning objectives can be achieved. Based on the background description, a problem arises. How to strengthen conservation values in listening skill learning?

This research provides ex pertise in the use of conservation values. During this time, various researches on skills to listen to people have been aware of the use of media, techniques, and learning models. In research of listening skill using the conservation values has not been done.

\section{Research Method}

This research was a class action research (PTK) consisting of four stages, namely planning, action, observation, reflection. Systematically, the research phase was applied in two cycles, namely cycle I and cycle II. The results of cycle I could also be used as a reference to implementation of cycle II. In cycle II this was carried out as a refinement of cycle I. The subject of this research was the listening learning of the students of Indonesian language and literature education. The research variables consisted of listening skill and conservation value. Data collection techniques used test and non-test techniques. Data analysis was performed by qualitative analysis.

\section{Results And Discussion}

The results of the first cycle test to strengthen the value of conservation in listening of Indonesian language and literature education students showed an average grade of 65 or sufficient in category. The assessment criteria for strengthening the value of conservation in listening learning includes three assessment groups, namely 1) the ability to understand the contents of the news, 2) the ability to determine the main points of the news, and 3) summarize the contents of the news in one paragraph. The results of the test of listening of the cycle I news are as follows.

There were no students who got the very good category with a score of 85-100, the good category with a score of 75-84 was only achieved by one student or by $2.9 \%$. The sufficient category with a score of $60-74$ reached 26 students or $77.1 \%$, then the less category with a score of $0-59$ achieved 3 students or $20 \%$. The low test results were still possible because the 
sound quality of the news recording was less than the maximum and the lack of seriousness in listening to the noise so that the power was reduced. This caused the students to be less optimal in understanding the news content. This was a reflection for the lecturer who are also the researcher to improve quality learning in cycle II.

The Strengthening of the value of conservation in listening learning of Indonesian language and literature education students in Semarang State University has increased in the second cycle. It was evident from the average value which was previously only 65 or enough to be 87 that was categorized as good and has reached the minimum passing grade.

The increase of the average value seen in each aspect 1) the ability to understand the contents of news is $34.6 \%$, from the value of 55.7 in the first cycle increased in the second cycle to $75 ; 2$ ) the ability to determine the main points in cycle I only increased by 51.4 to 75 in cycle II; and 3) summarizing the contents of the news in one paragraph in the first cycle of 65 to 87 . The negative student behavior in the first cycle also changed in a positive direction in the second cycle. If in cycle I students are not ready to accept the material to be taught, it is different from cycle II which shows the readiness of students to take part in listening learning activities. Provision of information about the material to be taught at the next meeting raises the enthusiasm of students to be better prepared for the second cycle of learning. The passive attitude of the students in the first cycle was also not visible in the second cycle. Ice breaking given by the lecturer at the beginning of the second cycle can melt the atmosphere and close the relationship between the lecturer and the students.

Based on the above data comparison, it can be concluded that the strengthening of conservation values in listening learning of the students of Indonesian language and literature education of Semarang State University in the second cycle is more orderly and organized. The use of learning media gives more experience to the students because they can implement the conversation value and be more skillful in listening. The changes of students behavior also have a pretty good influence on test scores. The seriousness and activeness of students during the learning process makes it easier for students to do the assignments given. This is evident from the increase in the average value of the test of strengthening the value of conservation in listening learning from cycle I to cycle II, in addition there has also been a change in students' behavior in a positive direction.

Research in listening skills by utilizing the value of conservation has never been done by anyone. Research on listening skills with strategies had been done by Ulper [11]. Research on listening skills using learning models was also conducted by Thompson et[5]. Further research to find out behavior changes students in learning listening skills had been done by Luchini[6]. In this research article using classroom action research. The results were to find out the competencies of learning outcomes and changes in behavior towards the positive. The use of conservation values has never been done by other researchers. Considering the value of conservation does not all universities use the use of these values. Therefore, it is necessary to explore these values so that they can be implemented in listening learning

Based on the results of this study it can be seen that the improvement in the competence of learning outcomes and changes in behavior towards students positively following listening to learning by utilizing the value of conservation. The increase of learning result and students' behavior in listening learning had been reported by Ulper [11] in article entitled the effect of Visual Strategies on Textual Structures in Listening Process to Comprehension Level of the Listeners "in the journal Procedia Social and Behavioral Sciences. The purpose of his research is to find the schematic structure of story text as a visual strategy on understanding listening skills. In the study found an increase in student understanding of listening activities that use the schematic structure of the story as a visual strategy in the classroom environment. In 
addition, it was found an increase in student understanding after listening to the activities using the schematic structure of the story as a visual strategy in the classroom environment.

The Journal of General Education entitled "The Integrative Listening Model: an Approach to the Teaching and Learning Listening Integrative Model" [12] model of integrative listening finds an increase in students' ability to understand information conveyed by others around them. In addition, it is also known that there is a change in behavior towards the desired goal through the listening process. The application of the model is carried out as a tool to develop students' listening abilities.Luchini confirmed his findings in the Journal of Language Studies entitled "Listening Skill Teaching: Some Pedagogical Considerations". The research found fundamental things in the behavior change of students to be skillful in listening. The change of behavior was in the form of motivation, self-confidence, and anxiety related to language acquisition. speaker, segmental characteristics, speech level, affective factors, environmental factors, listening material, and skills.

\section{Conclusion}

Based on the results of the study above, it can be concluded that the strengthening of the conservation value in listening learning of the students in Indonesian language and literature in Semarang State University has increased after participating in learning activities. The importance of conservation values is needed in listening learning. In the learning, it can be seen that students' behavior also changes in a positive direction in the listening learning process by implementing the conservation value of learning. In this research, it can be seen an increase in student learning outcomes, both through competence and behavior change in real learning.

\section{References}

[1] D. L. Naryatmojo, "Pemanfaatan Media Pembelajaran dalam Pembelajaran Keterampilan Menyimak untuk Meningkatkan Kompetensi Belajar Mahasiswa," Lap. Penelitian. Semarang, 2010.

[2] S. Graham, "Review of the book Listening in the language classroom," System, vol. 37, no. 3, pp. 540-541, 2009.

[3] J. Field, "Listening Skill and Strategies: Toward a New Methodologi for Learning," ELT J. Vol. 52/2 April, vol. Oxford Uni, p. 1998.

[4] F. A. Everest, Critical listening skills for audio professionals. 2007.

[5] R. Thompson, K. Peters, and D. Plaza, "Learning through listening: Applying an action learning model to a cross-cultural field study experience in Native America," Int. J. Intercult. Relations, vol. 28, no. 2, pp. 165-180, 2004.

[6] P. L. Luis, "Listening Skill Teaching: some Pedagogical Considerations," J. Lang. Stud., vol. Vol. 3. Ha, 2006

[7] S. BaLatur, "The Perceptions of EFL Prep School Students on their Listening Skills: A Quantitative Study," Procedia - Soc. Behav. Sci., vol. 232, no. April, pp. 806-812, 2016.

[8] S. Graham, D. Santos, and R. Vanderplank, "Listening comprehension and strategy use: A longitudinal exploration," System, vol. 36, no. 1, pp. 52-68, 2008.

[9] G. Brown, "Selective listening," System, vol. 36, no. 1, pp. 10-21, 2008

[10] V. Frunză, "The Listening Behavior in the Didactic Activity," Procedia - Soc. Behav. Sci., vol. 127, pp. 347-352, 2014.

[11] Hakan Ulper, "The effect of Visual Strategies on Textual Structures in Listening Process to 
Comprehension Level of the Listeners," Procedia Soc. Behav. Sci., pp. 568-574.

[12] Lynn O Cooper \& Trey Buchanan, "Listening Competency on Campus:A Psychometric Analysis of Student Listening,” Int. J. List., pp. 141-163, 2010. 